\title{
Effect of composition and drying method on glass transition temperature, water sorption characteristics and surface morphology of newly designed $\beta$-lactoglobulin/retinyl palmitate/ disaccharides systems
}

\author{
Agata Górska $^{1}$ - Karolina Szulc ${ }^{2}$ Ewa Ostrowska-Ligęza ${ }^{1} \cdot$ Joanna Bryś $^{1}$ \\ Magdalena Wirkowska-Wojdyła ${ }^{1}$
}

Received: 30 November 2016/Accepted: 6 April 2017/Published online: 19 April 2017

(c) The Author(s) 2017. This article is an open access publication

\begin{abstract}
In the study, MDSC method was used to evaluate thermal properties of $\beta$-lactoglobulin-retinyl palmitate products enriched in disaccharides. Additionally, sorption behavior of powders was determined to define their stability. The obtained powders were also examined and visualized with scanning electron microscopy to find the relationship between food processing conditions and morphological changes in products. For the samples tested, a single glass transition was observed. The results have shown the impact of the composition of studied samples on the glass transition temperatures. The carbohydrate- $\beta$ lactoglobulin systems were characterized by higher $T_{\mathrm{g}}$ values than disaccharides alone. At low water activity, all powdered complexes showed typical sorption behavior of food systems with the sigmoidal shape of the curve. The present study has shown that spray-dried and freeze-dried powdered products with lactose or trehalose have different time-dependent crystallization behavior. Trehalose as a carbohydrate component of samples, in comparison with lactose, delayed the occurrence of crystallization. The obtained images presented the dependence of the shape of the particles on the drying method used. Spray-dried powders were characterized by a spherical or close to spherical structure with the surface of larger particles often
\end{abstract}

Agata Górska

agata_gorska@sggw.pl

1 Department of Chemistry, Faculty of Food Sciences, Warsaw University of Life Sciences, 166 Nowoursynowska Street, 02-787 Warsaw, Poland

2 Department of Food Engineering and Process Management, Faculty of Food Sciences, Warsaw University of Life Sciences, 166 Nowoursynowska Street, 02-787 Warsaw, Poland deformed. In the case of freeze-dried particles, irregular structures were observed.

Keywords $\beta$-Lactoglobulin - Retinyl palmitate - MDSC . Thermal properties $\cdot$ Sorption isotherms $\cdot$ Scanning electron microscopy

\section{Introduction}

The fortification of food in vitamin A is usually carried out with some forms of fat. Nowadays, low-fat products become more popular, and consequently, the reduction of vitamin $\mathrm{A}$ in the diet rendered a nutritional concern. Searching for new possibilities to enrich products in vitamin $\mathrm{A}$ is a big challenge for scientists. $\beta$-lactoglobulin - a major whey protein - is of direct interest to the food industry since its properties can be advantageous in dairy products and processing. It is worth mentioning that biochemical oxygen demand of whey possesses a worldwide disposal and pollution problem for the dairy industry. It is urgently needed to search for new applications for whey proteins. The binding properties of $\beta$-lactoglobulin make it a potential ingredient to deliver retinyl palmitate in a form of spray- or freeze-dried powders to fat-free food systems [1-4]. Drying is the most commonly used method in production of stable food ingredients and food products. Powdered products are preferred by food industry because they are easier to transport, storage and handling. Freeze-drying is designed for unstable or heat labile foods and allows the production of high-quality dried products. High production costs, high energy consumptions and low throughputs limit often its application [5]. Spray drying is the dehydration process preferred for liquid food products with high initial moisture contents. 
The wide availability of the equipment, a large variety of carriers and good final product stability make the method one of the mostly used drying processes in the food industry $[6,7]$.

It is worth mentioning that rapid cooling or removal of solvent water during drying can result in the production of amorphous materials. Powdered food products, containing amorphous materials, such as disaccharides are prone to sticking, caking, collapse and crystallization, which are undesirable physical changes that can impact on quality and functionality of the final product [8]. Physical changes in food powders are related to the glass transition phenomenon. The most important change in the amorphous state occurs over the glass transition temperature $\left(T_{\mathrm{g}}\right)$, which is the temperature at which polymeric materials change from an amorphous solid (glass) to an amorphous rubber [9]. The glass transition temperature affects the texture of foods as well as storage stability of dried foods [10]. Understanding the glass transition phenomenon provides an insight into the causes of the cohesiveness of many important powders influencing the wettability or solubility of the powder, which is important for new product development. Food products are expected to be fairly stable below the $T_{\mathrm{g}}$, but when the temperature rises above $T_{\mathrm{g}}$, a solid structure is transformed to a supercooled liquid state with time-dependent flow. The glass transition behavior of disaccharides (lactose, trehalose) is well known, but higher $T_{\mathrm{g}}$ may be observed for carbohydrateprotein systems than for carbohydrates alone [11, 12]. Differential scanning calorimetry (DSC) is the most widely used thermal analysis technique to measure the temperature and heat flows associated with phase transitions in materials, as a function of time and temperature. Such measurements can provide both quantitative information and qualitative information concerning physical and chemical changes that involve endothermic and exothermic processes, or changes in heat capacity. DSC is particularly suitable for analysis of food systems because they are often subject to heating or cooling during processing. The calorimetric information from DSC can be directly used to understand the thermal transitions that the food system undergoes during processing or storage [13-17]. Modulated differential scanning calorimetry (MDSC) which is an enhancement to conventional DSC and involves the application of a sinusoidal heating or cooling signal to a sample and the subsequent measurement of the reversing and non-reversing components of the heat flow response is widely used technique for studying the glass transition [18-21].

Disaccharides such as trehalose and lactose are commonly used to protect biomolecules from drying-related stresses [22]. They were found to limit the conformational changes and stabilize whey proteins during spray drying
[23]. The saccharides are able to form a glassy state of a very high viscosity and low mobility and restrict the mobility of protein as well as its unfolding [24]. Additives such as lactose and trehalose remain in the amorphous phase with the protein and bind to the protein in the place of water during drying that prevent the stability problems. Crystallization is a phase transition occurring in freezedried and spray-dried amorphous lactose, trehalose or other crystallizing carbohydrates. Crystallization occurs time dependently when water content or temperature exceeds a critical value [25]. A number of researchers have investigated lactose [26, 27] or trehalose [28] crystallization occurring in powdered mixtures during water sorption in storage.

Water vapor sorption behavior and glass-rubber transition data provide information that is useful in selecting processing conditions for dried powders, and that influence physical characteristics (hygroscopicity, stickiness and caking behavior) and stability (storing and handling) of the final product. Water vapor sorption isotherms show the quantity of water absorbed by powders and the relative humidity at which carbohydrate crystallizes in powders [29, 30].

The aim of the present study was to determine the effect of disaccharides incorporation and the parameters used in the drying process on thermal and sorption properties of $\beta$ lactoglobulin-retinyl palmitate powdered complexes. The knowledge of $T_{\mathrm{g}}$ profiles together with isotherms provides important information about the stability of powdered products enriched in disaccharides. Additionally, the morphology of particles was discussed.

\section{Materials and methods}

\section{Materials}

BioPURE $\beta$-lactoglobulin containing 95\% $\beta$-lactoglobulin was provided as powder by Davisco Foods International, Inc. (Le Sueur, Minnesota). Retinyl palmitate and $\alpha$-lactose monohydrate were purchased from Sigma Chemical Co. (St. Louis, Missouri) and were of the highest analytical quality. Trehalose was purchased from Hortimex Ltd Co. (Konin, Poland).

\section{Methods}

\section{Solution preparation}

$400 \mathrm{~mL}$ of $\beta$-lactoglobulin $\left(M=18400 \mathrm{~g} \mathrm{~mol}^{-1}\right)$ solution was prepared by gently adding distilled water into $8.6 \mathrm{~g}$ $(0.47 \mathrm{mmol})$ of the protein while stirring slowly to avoid heavy foaming. The mixture was kept at room temperature 
until a homogenous clear solution was formed. Then, $0.50 \mathrm{~g}(0.94 \mathrm{mmol})$ of retinyl palmitate (vitamin A) dissolved in $800 \mu \mathrm{L}$ absolute ethanol was added into the solution to obtain 2:1 molar ratio of vitamin A to protein. The solution was incubated at $40{ }^{\circ} \mathrm{C}$ for $2 \mathrm{~h}$ according to the method described by Kontopidis et al. [3]. Then, lactose or trehalose was added to the $\beta$-lactoglobulin-retinyl palmitate solution in a mass ratio 5:1. The formulations were mixed until disaccharides were dissolved and then dried.

\section{Spray drying}

The aqueous $\beta$-LG-vitamin A-carbohydrates solutions were spray-dried in a laboratory spray-dryer Lab S1 (Anhydro, Denmark) by a peristaltic pump and atomized to small droplets by a spray disk speed of $39.000 \mathrm{rpm}$. The operational conditions of the spray drying were: air inlet temperature: 120 and $160{ }^{\circ} \mathrm{C}$, and raw material flux rate: 51.4 and $64.2 \mathrm{~mL} \mathrm{~min}^{-1}$. The powders were kept in plastic bags and stored in vacuum desiccators over $\mathrm{CaCl}_{2}$ at room temperature, in a dry and dark place until further analysis.

\section{Freeze-drying}

Before freeze-drying, the aqueous solutions were frozen at $-40{ }^{\circ} \mathrm{C}$ for $4 \mathrm{~h}$. Frozen samples were placed on the shelves of a Gamma 1-16 LDC freeze dryer (Christ Company, Germany). The freeze-drying process was conducted for $24 \mathrm{~h}$ under a constant pressure of $63 \mathrm{~Pa}$ at a constant shelf temperature of $30{ }^{\circ} \mathrm{C}$. The powders were kept in plastic bags and stored in vacuum desiccators over $\mathrm{CaCl}_{2}$ at room temperature, in a dry and dark place until further analysis.

\section{MDSC studies}

Modulated DSC experiments were performed on a TA Instrument Q200 differential scanning calorimeter (New Castle, USA). Modulated differential scanning calorimetry (MDSC) was used to determine the glass transition temperature of $\beta$-lactoglobulin-retinyl palmitate powders with lactose or trehalose addition at water activity about 0 . The cell was purged with $50 \mathrm{~mL} \mathrm{~min}^{-1}$ dry nitrogen and calibrated for baseline on an empty oven and for temperature using standard pure indium. An empty sealed aluminum pan was used as a reference in each test. Powders (10-13 mg) were non-hermetically sealed in aluminum pans (volume $30 \mu \mathrm{L}$ ) and cooled from room temperature to $10{ }^{\circ} \mathrm{C}$ at heating rate $5{ }^{\circ} \mathrm{C}$ per min and equilibrated for $5 \mathrm{~min}$. In the case of MDSC, samples were scanned from 10 to $170{ }^{\circ} \mathrm{C}$ at a constant cooling rate of $2{ }^{\circ} \mathrm{C}$ per min with an amplitude of $\pm 1{ }^{\circ} \mathrm{C}$ and 60 s period of modulation. Curves were analyzed with respect to the total, reversible and non-reversible heat flow [31, 32]. Glass transition was reported with parameters indicating its onset, midpoint and endpoint of a vertical shift in the reversing transition curve. TA Instruments Universal Analysis software was used to analyze the glass transition temperature. The measurements were carried out in three replicates for each sample.

\section{Sorption isotherms}

Water vapor sorption isotherms were determined using the static gravimetric method. The products were stored at a stable relative humidity, which ranged from 0.0 to 0.92 , for 3 months [23, 24]. The products to be analyzed were placed in desiccators and were kept at a constant temperature of $25{ }^{\circ} \mathrm{C}$. Saturated salt solutions were prepared as hygroscopic factors. The salts used were: $\mathrm{CaCl}_{2}, \mathrm{LiCl}$, $\mathrm{CH}_{3} \mathrm{COOK}, \mathrm{MgCl}_{2}, \mathrm{~K}_{2} \mathrm{CO}_{3}, \mathrm{Mg}\left(\mathrm{NO}_{3}\right)_{2}, \mathrm{NaNO}_{2}, \mathrm{NaCl}$, $\left(\mathrm{NH}_{4}\right)_{2} \mathrm{SO}_{4}$ and $\mathrm{NH}_{4} \mathrm{H}_{2} \mathrm{PO}_{4}$ with corresponding water activities of $0,0.11,0.23,0.33,0.44,0.53,0.65,0.75,0.81$ and 0.92 , respectively [28].

Table 1 Composition and drying method for products A1-A10

\begin{tabular}{|c|c|c|}
\hline Sample & Composition & Method of drying \\
\hline A1 & $\begin{array}{l}\beta \text {-Lactoglobulin-vitamin } \\
\text { A-lactose }\end{array}$ & $\begin{array}{l}\text { Spray drying, inlet air } \\
\text { temperature } 120^{\circ} \mathrm{C} \text {, material } \\
\text { feed flux } 51.4 \mathrm{~mL} \mathrm{~min}{ }^{-1}\end{array}$ \\
\hline $\mathrm{A} 2$ & $\begin{array}{l}\beta \text {-Lactoglobulin-vitamin } \\
\text { A-lactose }\end{array}$ & $\begin{array}{l}\text { Spray drying, inlet air } \\
\text { temperature } 120^{\circ} \mathrm{C} \text {, material } \\
\text { feed flux } 64.2 \mathrm{~mL} \mathrm{~min}{ }^{-1}\end{array}$ \\
\hline A3 & $\begin{array}{l}\beta \text {-Lactoglobulin-vitamin } \\
\text { A-lactose }\end{array}$ & $\begin{array}{l}\text { Spray drying, inlet air } \\
\text { temperature } 160{ }^{\circ} \mathrm{C} \text {, material } \\
\text { feed flux } 51.4 \mathrm{~mL} \mathrm{~min}\end{array}$ \\
\hline A4 & $\begin{array}{l}\beta \text {-Lactoglobulin-vitamin } \\
\text { A-lactose }\end{array}$ & $\begin{array}{l}\text { Spray drying, inlet air } \\
\text { temperature } 160{ }^{\circ} \mathrm{C} \text {, material } \\
\text { feed flux } 64.2 \mathrm{~mL} \mathrm{~min}{ }^{-1}\end{array}$ \\
\hline A5 & $\begin{array}{l}\beta \text {-Lactoglobulin-vitamin } \\
\text { A-trehalose }\end{array}$ & $\begin{array}{l}\text { Spray drying, inlet air } \\
\text { temperature } 120^{\circ} \mathrm{C} \text {, material } \\
\text { feed flux } 51.4 \mathrm{~mL} \mathrm{~min}\end{array}$ \\
\hline A6 & $\begin{array}{l}\beta \text {-Lactoglobulin-vitamin } \\
\text { A-trehalose }\end{array}$ & $\begin{array}{l}\text { Spray drying, inlet air } \\
\text { temperature } 120^{\circ} \mathrm{C} \text {, material } \\
\text { feed flux } 64.2 \mathrm{~mL} \mathrm{~min}{ }^{-1}\end{array}$ \\
\hline A7 & $\begin{array}{l}\beta \text {-Lactoglobulin-vitamin } \\
\text { A-trehalose }\end{array}$ & $\begin{array}{l}\text { Spray drying, inlet air } \\
\text { temperature } 160{ }^{\circ} \mathrm{C} \text {, material } \\
\text { feed flux } 51.4 \mathrm{~mL} \mathrm{~min}\end{array}$ \\
\hline A8 & $\begin{array}{l}\beta \text {-Lactoglobulin-vitamin } \\
\text { A-trehalose }\end{array}$ & $\begin{array}{l}\text { Spray drying, inlet air } \\
\text { temperature } 160{ }^{\circ} \mathrm{C} \text {, material } \\
\text { feed flux } 64.2 \mathrm{~mL} \mathrm{~min}{ }^{-1}\end{array}$ \\
\hline A9 & $\begin{array}{l}\beta \text {-Lactoglobulin-vitamin } \\
\text { A-lactose }\end{array}$ & $\begin{array}{l}\text { Freeze-drying, temperature of } \\
\text { heating shelves in freeze } \\
\text { dryer } 30^{\circ} \mathrm{C}\end{array}$ \\
\hline A10 & $\begin{array}{l}\beta \text {-Lactoglobulin-vitamin } \\
\text { A-trehalose }\end{array}$ & $\begin{array}{l}\text { Freeze-drying, temperature of } \\
\text { heating shelves in freeze } \\
\text { dryer } 30^{\circ} \mathrm{C}\end{array}$ \\
\hline
\end{tabular}




\section{Sorption kinetics}

The measurement of water vapor sorption kinetics was conducted using a stand which ensured continuous measurement of mass increase in the conditions of constant temperature and relative humidity [28]. Adsorption kinetics was determined at a temperature of $25^{\circ} \mathrm{C}$ within $24 \mathrm{~h}$ at three levels of relative humidity of the environment $(0.33,0.65$ and 0.92$)$ obtained using saturated $\mathrm{MgCl}_{2}, \mathrm{NaNO}_{2}$ and $\mathrm{NH}_{4} \mathrm{H}_{2} \mathrm{PO}_{4}$ solutions. The investigated samples mass increase was registered using the measurement for DOS software.

\section{Analysis of the morphology of the obtained powder particles}

Analysis of the sample structure was carried out on the basis of the obtained images. The morphology of studied powders was examined using scanning electron microscope (SEM), FEI QUANTA 200 with EDS microanalyzer and digital video recording. Photographs were taken at a voltage prevailing in the generator of $30 \mathrm{kV}$, the distance of the head from a sample of $10 \mathrm{~mm}$ and a pressure of 1 Torr. FLD detector was used. Analysis of images was performed using the program MultiScan v 13.1.

\section{Statistical analysis}

Each measurement was triplicate. The data were reported as the mean \pm standard deviation. Two-way ANOVA was conducted using Statgraphics Plus for Windows program, version 4.1 (Statistical Graphics Corporation, Warrenton, VA, USA). Differences were considered to be significant at a $p$ value of 0.05 , according to Tukey's multiple range test.

\section{Results and discussion}

In the study, powdered products (A1-A10) diverse in terms of composition and method of drying were obtained (Table 1).

It has been proved that glass transition temperature can be an effective indicator for food quality changes during storage [12]. In the present study, DSC curves of reversing heat flow versus temperature were recorded to determine glass transitions' temperatures of products. The example of such DSC curve is shown in Fig. 1.

The glass transitions presented in Table 2 are reported with parameters indicating their onset, midpoint and endpoint, so the width of the transitions is clear. In the case of $\beta$-lactoglobulin-retinyl palmitate powders enriched in disaccharides, a single glass transition was observed. In the case of lactose incorporation, the values of glass transition temperatures were lower than in the case of trehalose presence in the product. In the samples containing lactose, the onset $T_{\mathrm{g}}$ ranged from $111.45 \pm 1.35$ to $113.07{ }^{\circ} \mathrm{C} \pm 1.98$, the midpoint $T_{\mathrm{g}}$ from $113.05 \pm 1.37$ to $115.60{ }^{\circ} \mathrm{C} \pm 1.15$ and the endpoint $T_{\mathrm{g}}$ from $115.16 \pm 1.58$

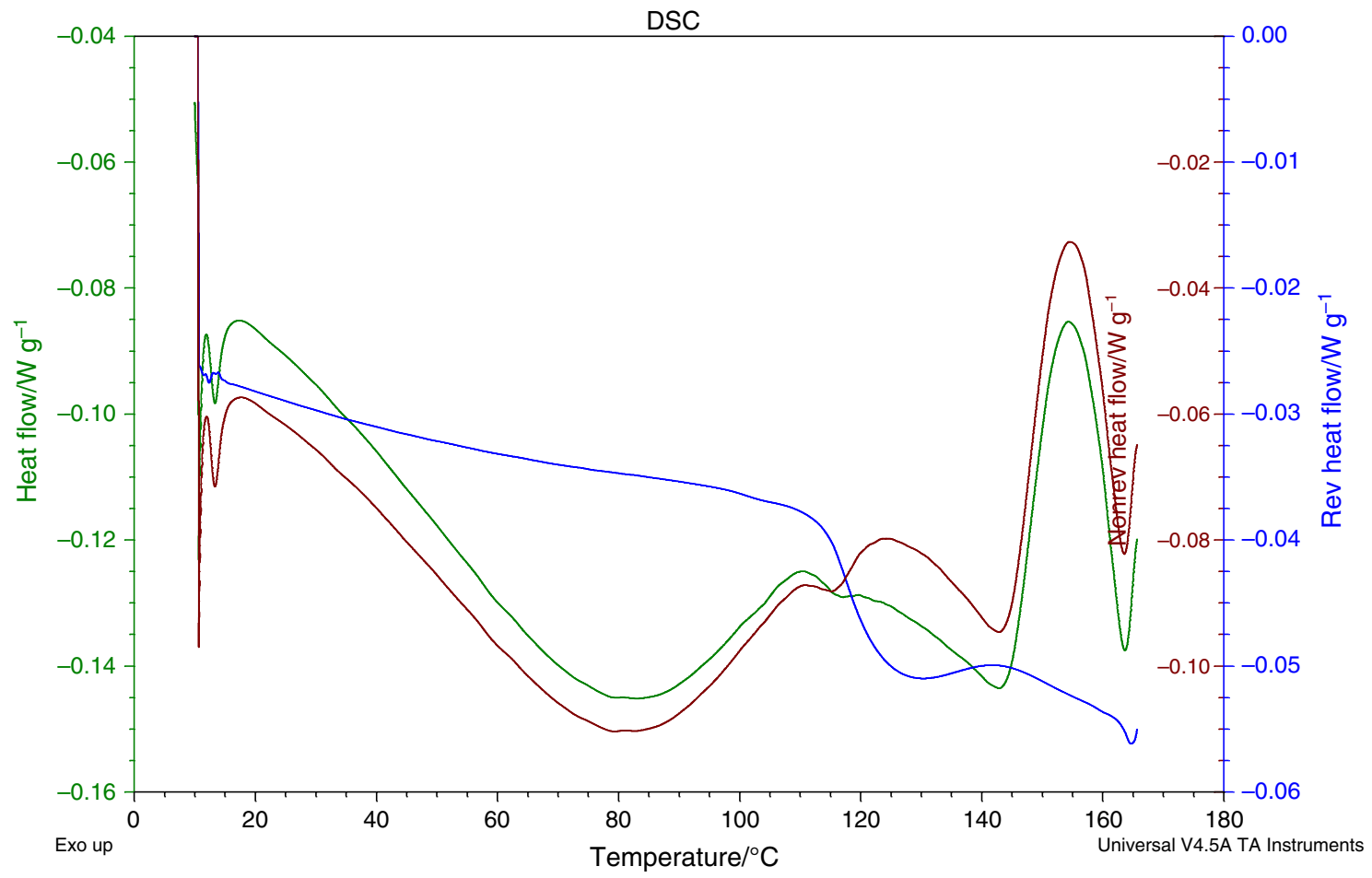

Fig. 1 DSC curve of reversing heat flow versus temperature of $\beta$-lactoglobulin-retinyl palmitate-trehalose powder obtained by spray drying 
Table 2 Experimental glass transition temperatures of $\beta$-lactoglobulin-vitamin A complexes with the addition of lactose (A1-A4, A9) or trehalose (A5-A8, A10)

\begin{tabular}{llll}
\hline Sample & $T_{\mathrm{g}}$ onset $/{ }^{\circ} \mathrm{C}$ & $T_{\mathrm{g}}$ midpoint $/{ }^{\circ} \mathrm{C}$ & $T_{\mathrm{g}}$ endpoint $/{ }^{\circ} \mathrm{C}$ \\
\hline A1 & $111.45 \pm 1.35^{\mathrm{a}}$ & $113.05 \pm 1.37^{\mathrm{a}}$ & $115.16 \pm 1.58^{\mathrm{a}}$ \\
$\mathrm{A} 2$ & $112.75 \pm 0.99^{\mathrm{a}}$ & $113.55 \pm 1.44^{\mathrm{a}}$ & $115.81 \pm 1.18^{\mathrm{a}}$ \\
A3 & $113.07 \pm 1.98^{\mathrm{a}}$ & $115.60 \pm 1.15^{\mathrm{a}}$ & $116.90 \pm 0.87^{\mathrm{a}}$ \\
A4 & $112.48 \pm 1.85^{\mathrm{a}}$ & $114.88 \pm 1.90^{\mathrm{a}}$ & $115.43 \pm 1.54^{\mathrm{a}}$ \\
A5 & $118.45 \pm 1.00^{\mathrm{b}}$ & $120.05 \pm 1.37^{\mathrm{b}}$ & $122.16 \pm 1.58^{\mathrm{b}}$ \\
A6 & $118.76 \pm 0.99^{\mathrm{b}}$ & $120.55 \pm 1.44^{\mathrm{b}}$ & $121.81 \pm 1.18^{\mathrm{b}}$ \\
A7 & $118.98 \pm 1.98^{\mathrm{b}}$ & $121.60 \pm 1.15^{\mathrm{b}}$ & $122.90 \pm 0.87^{\mathrm{b}}$ \\
A8 & $118.48 \pm 1.85^{\mathrm{b}}$ & $121.88 \pm 1.90^{\mathrm{b}}$ & $122.68 \pm 1.54^{\mathrm{b}}$ \\
A9 & $112.96 \pm 1.85^{\mathrm{a}}$ & $113.24 \pm 1.34^{\mathrm{a}}$ & $117.14 \pm 0.85^{\mathrm{a}}$ \\
A10 & $118.96 \pm 1.85^{\mathrm{b}}$ & $120.24 \pm 1.34^{\mathrm{b}}$ & $123.14 \pm 0.85^{\mathrm{b}}$ \\
\hline
\end{tabular}

Values represent means \pm standard deviations

Different letters indicate that the samples are considered significantly different at the $5 \%$ level $(p<0.05)$

to $117.14{ }^{\circ} \mathrm{C} \pm 0.85$. In the case of $\beta$-lactoglobulin-vitamin A-trehalose powders, the onset $T_{\mathrm{g}}$ ranged from $118.45 \pm 1.00$ to $118.98{ }^{\circ} \mathrm{C} \pm 1.98$, the midpoint $T_{\mathrm{g}}$ from $120.05 \pm 1.37$ to $121.88^{\circ} \mathrm{C} \pm 1.90$ and the endpoint $T_{\mathrm{g}}$ from $121.81 \pm 1.18$ to $123.14{ }^{\circ} \mathrm{C} \pm 0.85$. Similar results were observed in the case of $\beta$-lactoglobulin-cholecalciferol-lactose powdered products. The onset glass transition temperature of the samples in the study ranged from $112.93 \pm 1.08$ to $112.99{ }^{\circ} \mathrm{C} \pm 0.96$, the midpoint $T_{\mathrm{g}}$ from $118.42 \pm 1.27$ to $119.20^{\circ} \mathrm{C} \pm 1.18$ and the endpoint $T_{\mathrm{g}}$ from $122.07 \pm 1.01$ to $125.08{ }^{\circ} \mathrm{C} \pm 1.92$ [33]. The obtained results show that glass transition temperatures vary depending on the composition of studied complexes. The effect of disaccharides incorporation on the glass transition temperatures was observed. It is worth mentioning that carbohydrate-protein systems were characterized by higher $T_{\mathrm{g}}$ values than disaccharides (lactose, trehalose) alone. The obtained results are in agreement with researches presented by Haque and Roos, who studied water sorption and plasticization behavior of spray-dried lactose/protein mixtures [11]. The higher $T_{\mathrm{g}}$ of carbohydrate-protein mixtures may increase the stability of the final food products. The method and parameters of drying did not affect the values of $T_{\mathrm{g}}$. The results confirmed the statement that the glass transition temperatures of foods are mainly dependent on the moisture content and chemical composition of the material [28, 31, 33].

Figure 2 shows the sorption isotherm curves obtained for powdered complexes at the temperature of $25{ }^{\circ} \mathrm{C}$. For all powders, sigmoidal shape typical for the most foods, independently of drying methods and process parameters, was observed. Sorption isotherms of powdered complexes with lactose as a main component showed a decrease in mass at water activity of $0.44-0.65$ (Fig. 2a). The loss of
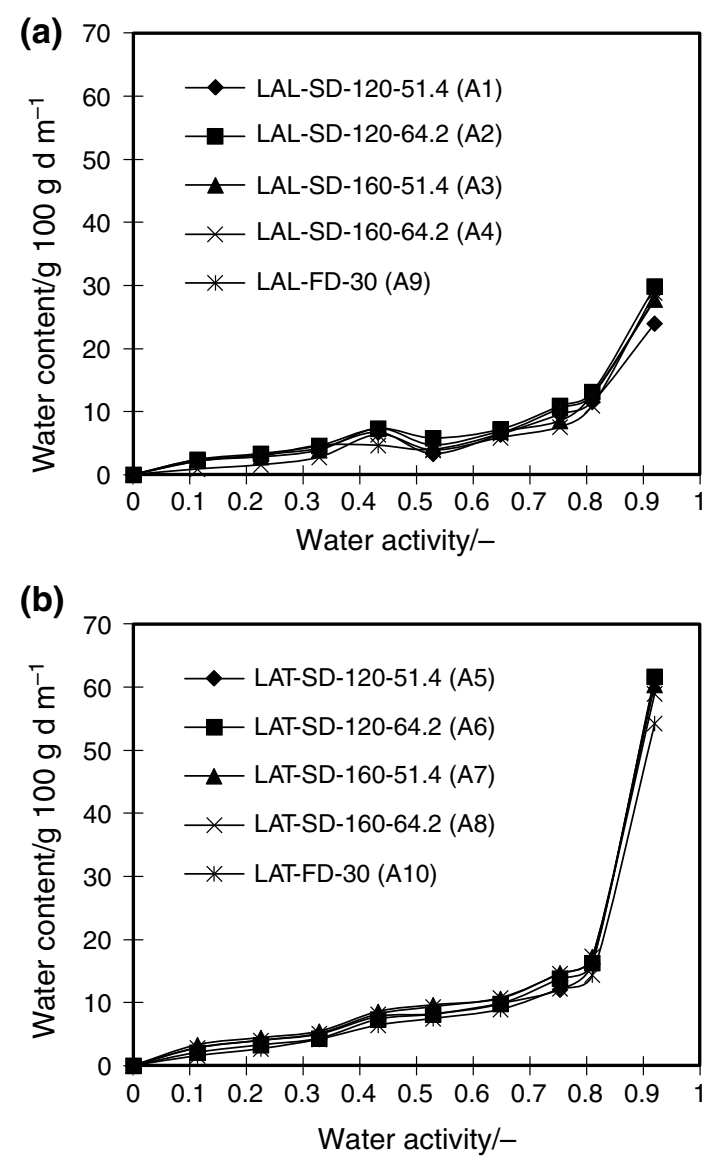

Fig. 2 Water vapor sorption isotherms of powdered complexes: a $\beta$ lactoglobulin-vitamin A-lactose and b $\beta$-lactoglobulin-vitamin Atrehalose

sorbed water was due to the process of lactose crystallization. Sugars in some processed foods, such as spraydried or freeze-dried, are usually present in the amorphous state. All amorphous sugars are hygroscopic and have a strong tendency to absorb the surrounding water $[30,34,35]$. The amount of water sorbed by powdered $\beta$ lactoglobulin-vitamin A-trehalose products (A5-A6, A10) increased within full range of water activity (Fig. 2b). Crystallization has not been observed for these complexes. The results are in agreement with researches conducted by Sitaula and Bhowmick [36], in which crystallization in the trehalose-PBS (phosphate-buffered saline) mixtures was not observed. The amount of water sorbed by complexes containing lactose (A1-A4, A9) was lower comparing to those with trehalose (A5-A8, A10). The final water content depends on the type of sugar crystalline structure and other components. Sugars that form hydrated crystals (trehalose) retain higher amounts of water than sugars that form anhydrous crystals (lactose) [34, 35].

Adsorption kinetics of $\beta$-lactoglobulin-vitamin A-carbohydrates complexes are given in Fig. 3. At low water activity (0.33), all powdered complexes showed typical 
(a) $a_{w}=0.33$

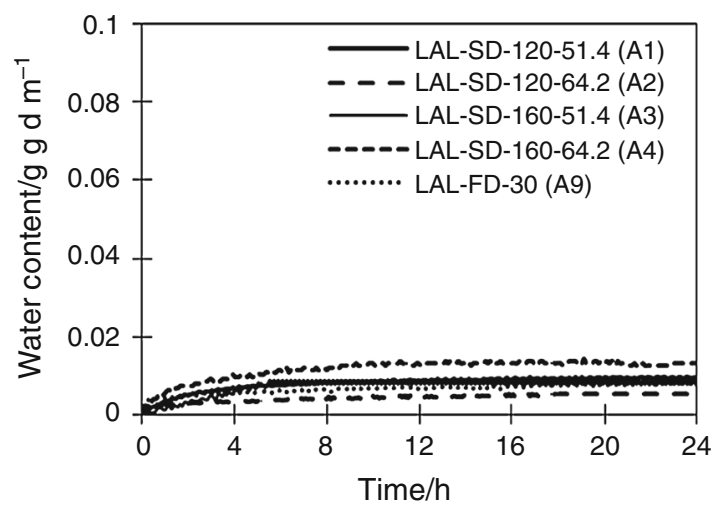

(b) $a_{w}=0.33$

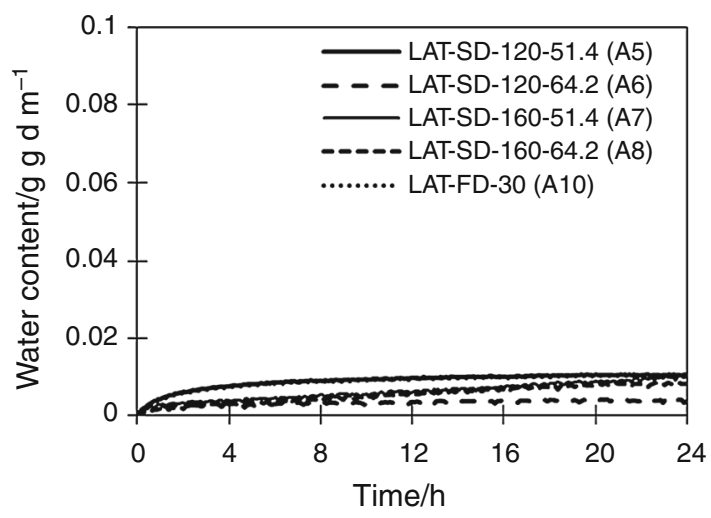

(c) $a_{w}=0.65$

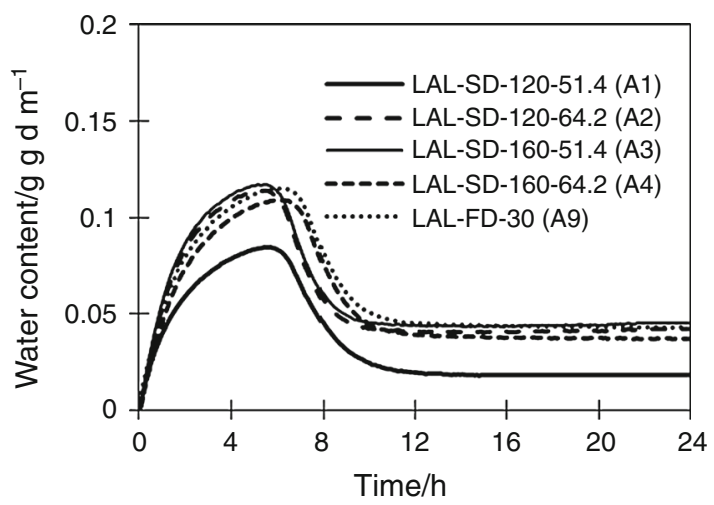

(d) $a_{w}=0.65$

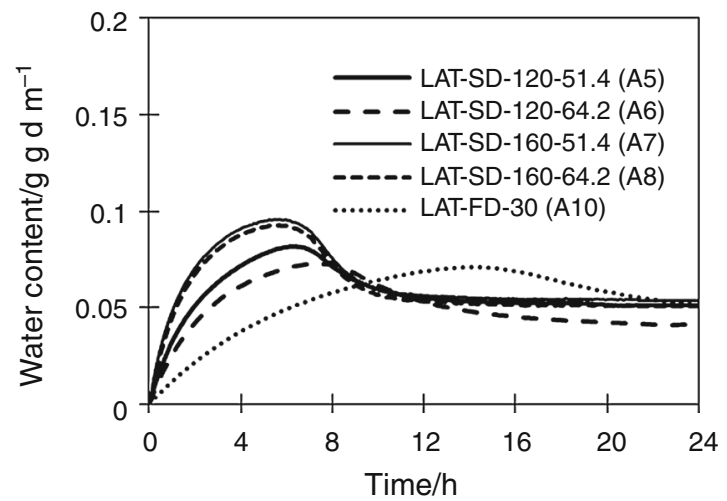

(e) $a_{w}=0.92$

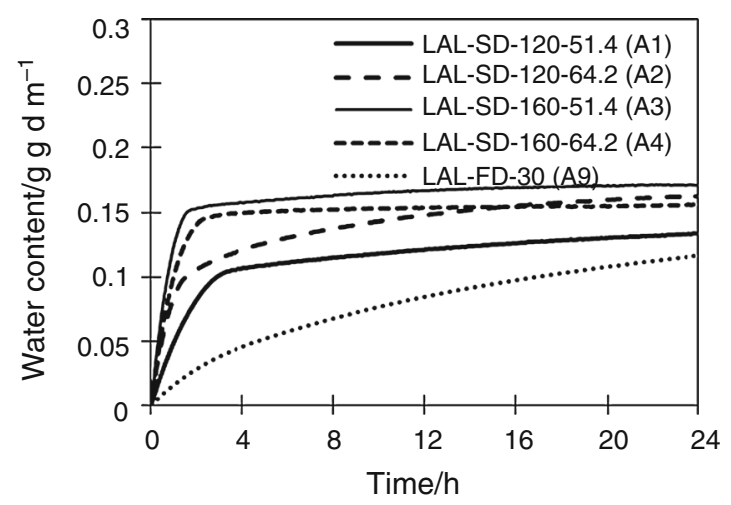

(f) $\mathrm{a}_{\mathrm{w}}=0.92$

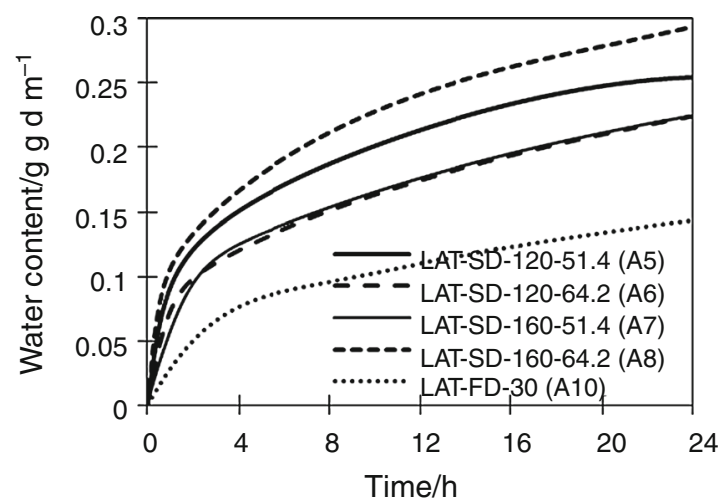

Fig. 3 Water vapor sorption kinetics of powdered complexes: $\beta$-lactoglobulin-vitamin A-lactose (a, c, e) and $\beta$-lactoglobulin-vitamin Atrehalose $(\mathbf{b}, \mathbf{d}, \mathbf{f})$

sorption behavior of food powders (Fig. 3a, b). Powdered complexes with lactose or trehalose did not show loss of sorbed water at relative humidity of $33 \%$. After $24 \mathrm{~h}$ of adsorption at water activity of 0.33 , the lowest hygroscopicity was observed for the powders obtained by spray drying at inlet temperature of $120{ }^{\circ} \mathrm{C}$ and flux rate $64.2 \mathrm{~mL} \mathrm{~min}^{-1}$, independently of carbohydrates used. Lactose crystallization was observed in complexes at water activity of 0.65 , independently of process parameters of spray drying or freeze-drying (Fig. 3c). Loss of sorbed water in spray-dried and freeze-dried products with lactose as the main component was observed after the same period of time $(<5 \mathrm{~h})$. Similar results were obtained by Haque and Roos [25], who described that powdered lactose/protein mixtures crystallized when the material was stored at water activity 0.65 . Trehalose as a main carbohydrate component 
of powdered samples A5-A8 and A10, in comparison with lactose, reduced the occurrence of crystallization. In powdered $\beta$-LG-vitamin A-trehalose complex (A10) obtained by freeze-drying, crystallization was observed after $14 \mathrm{~h}$ of water vapor adsorption (Fig. 3d). The loss of adsorbed water at water activity of 0.65 in $\beta$-LG-vitamin A-carbohydrate system is the result of carbohydrate crystallization. Crystallization properties of lactose and trehalose are quite different [22]. It was observed that crystallization in powders with trehalose was delayed in comparison with those containing lactose. Carbohydrates (lactose, trehalose) crystallization has occurred in some processed foods (spray drying, freeze-drying), independently on the operating conditions $[22,28]$. Lactose or trehalose crystallization was not observed in samples stored at water activity 0.92 for both types of powders (Fig. 3e, f). Freeze-dried complexes with lactose and trehalose sorbed less amounts of water than spray-dried powders at higher relative humidity (92\%).

In recent years, the study of the microstructure of food is of increasing significance since the structure of foods can have a profound influence on its nutritional value, rheology and textural attributes. Food processing, such as thermal and nonthermal processes, can alter the natural structure and the composition of food materials [37, 38]. The technique that is widely used to study the influence of processing conditions and ingredients on food structure is scanning electron microscopy (SEM) [39-41]. It is a very useful tool to visualize food structure because it combines the best features of light microscopy (LM) and transmission electron microscopy (TEM). The obtained powdered products were examined and visualized with SEM. Images are presented in Figs. 4-6. In the studied samples, visible differences in the shapes of the particles obtained by different drying methods can be observed (Fig. 4a, b). The powders obtained by spray drying had a spherical or close
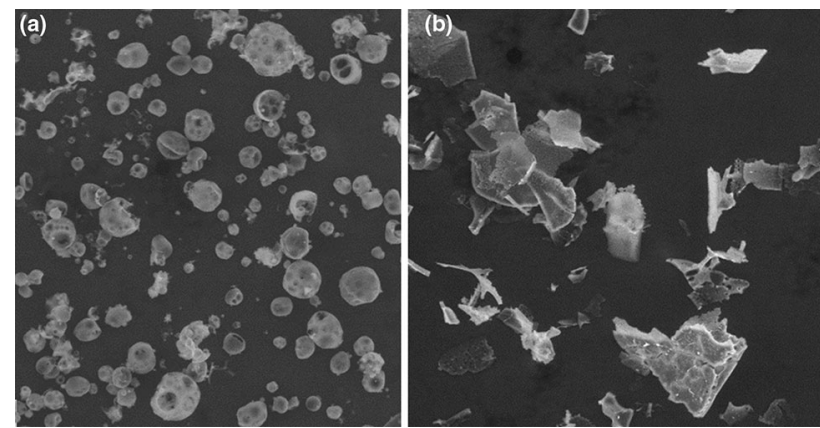

Fig. 4 SEM images (magnification $\times 400$ ) illustrating the morphology of $\beta$-lactoglobulin-vitamin A-lactose particles obtained in the form of powders by a spray drying with an inlet air temperature of $120{ }^{\circ} \mathrm{C}$ and $\mathbf{b}$ freeze-drying with the temperature of heating shelves in freeze dryer $30{ }^{\circ} \mathrm{C}$
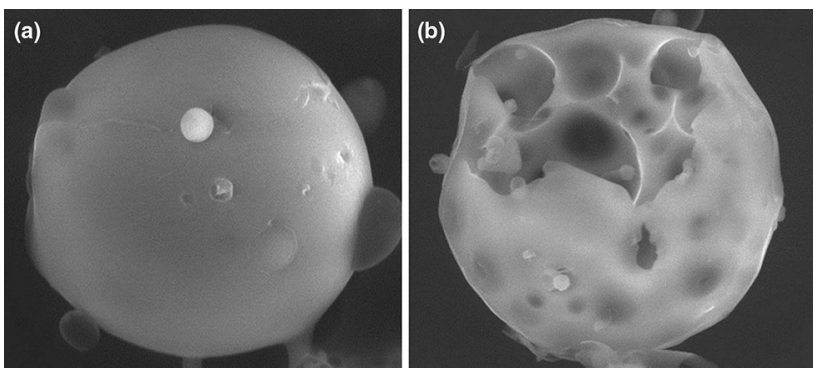

Fig. 5 SEM images (magnification $\times 4000$ ) illustrating the morphology of $\beta$-lactoglobulin-vitamin A-lactose particles obtained in the form of powders by spray drying with an inlet air temperature of a $120^{\circ} \mathrm{C}$ and b $160{ }^{\circ} \mathrm{C}$

to spherical structure and a great diversity of size. The surface of larger particles was often deformed (Fig. 5a, b). The fine particles were concentrated in the immediate vicinity of large components. In the case of spray-dried products, SEM images showed the presence of semispherical microcapsules which showed dents and rough surfaces but no evidence of fracture (Figs. 4a, 5a, b). From the SEM images, it can be observed that lower drying temperature led to relatively uniform size and shape with smooth particle surface, whereas higher drying temperature resulted in size variations and wrinkled particle surfaces (Fig. 5a, b). Krishnan et al. [42] evaluated the blend of carriers for encapsulation of cardamom oleoresin. Microcapsules were found to be nearly spherical, but had many dents on the surface. The morphology of powders which were produced with blend of carriers was spherical and had a smooth surface. Among the drying methods which are used in food processing industries, freeze-drying is considered one of the most advanced methods for drying high value products sensitive to heat. Freeze-drying is carried out in two stages: the product is first frozen, and then, the ice is removed by sublimation directly from the solid to the vapor phase. During freeze-drying, ice sublimation causes significant changes in the shape and volume of the food products. Depending on the process conditions, pores or gaps with different characteristics are created by the ice crystals which sublimated [43, 44]. The studied freezedried particles were characterized by irregular structure (Fig. 6). A denser structure with less pore sizes resulting in harder texture was observed (Figs. 4b, 6). The origin of this morphology is probably due to the freeze-drying processing technique used in this work. Similar results were obtained by Oikonomopoulou et al. [45]. They used SEM to visualize the microstructure of freeze-dried rice kernels and observed particles of different shapes. The increase in boiling time caused the increase in both porosity and average pore size. Rhim et al. [46] also employed scanning electron microscope to investigate the microstructure of freeze-dried rice porridge samples. SEM results showed 


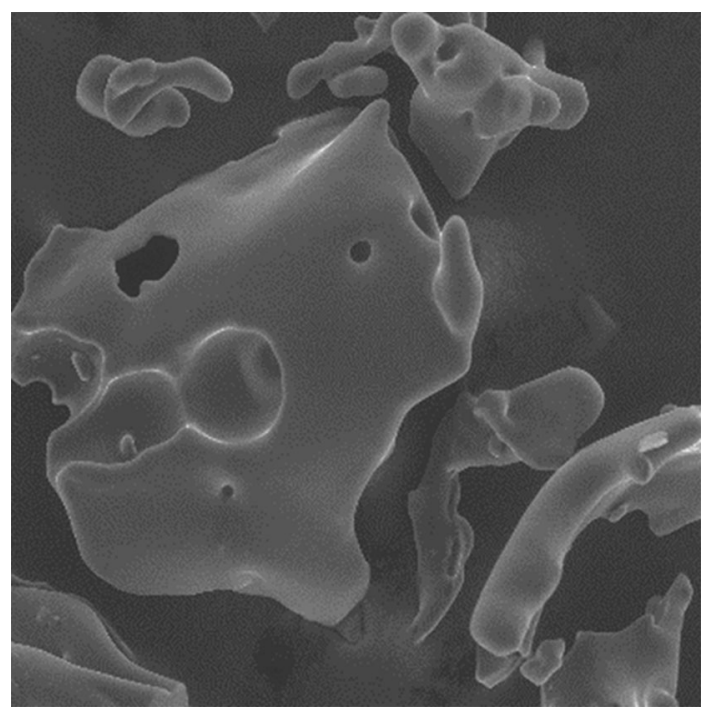

Fig. 6 SEM images (magnification $\times 4000$ ) illustrating the morphology of $\beta$-lactoglobulin-vitamin A-lactose particles obtained in the form of powders by freeze-drying with the temperature of heating shelves in freeze dryer $30^{\circ} \mathrm{C}$

rigid and porous cube type rice porridges that were obtained after freeze dehydration. No shrinkage was observed with all samples.

\section{Conclusions}

The obtained results have shown the disaccharides impact on thermal properties of the final products. The glass transition temperatures were dependent on the composition of studied samples. In the case of trehalose incorporation into products, the temperatures were higher than in samples containing lactose. The carbohydrate- $\beta$-lactoglobulin systems were characterized by higher $T_{\mathrm{g}}$ values than disaccharides alone. In food systems, a higher $T_{\mathrm{g}}$ can be assumed to improve protection and stability of encapsulated compounds, such as vitamin A. Sorption isotherm curves obtained for powdered complexes showed the sigmoidal shape. The amount of water sorbed by powdered $\beta$-lactoglobulin-vitamin A-lactose complexes was lower comparing to those with trehalose, independently of environmental water activity. The present study has shown that spray-dried and freeze-dried powdered complexes with lactose or trehalose have different time-dependent crystallization behavior. In the case of $\beta$-lactoglobulin-vitamin A-trehalose products, the carbohydrate crystallization at water activity of 0.65 was delayed in comparison with $\beta$-lactoglobulin-vitamin A-lactose samples. The addition of trehalose to food systems could improve the quality of the powders by delaying crystallization. It is of great importance because the extent of crystallization is critical to acceptance of the final product. The study showed the impact of different drying methods on the shapes of the particles. The powders obtained by spray drying had a spherical or close to spherical structure and a great diversity of size. The surface of larger particles was often deformed. The studied freeze-dried particles were characterized by irregular structure. The information on microstructure changes is essential for finding the relationship between food processing conditions and morphological changes of the food components. It enables better process control and improvement in the appearance of the sample by optimizing pretreatment and drying parameters. As the structure of foods can have a profound influence on its nutritional value, the proper conditions can help to retain the quality of the final product.

Open Access This article is distributed under the terms of the Creative Commons Attribution 4.0 International License (http://creative commons.org/licenses/by/4.0/), which permits unrestricted use, distribution, and reproduction in any medium, provided you give appropriate credit to the original author(s) and the source, provide a link to the Creative Commons license, and indicate if changes were made.

\section{References}

1. Brownlow S, Cabral JHM, Cooper R, Flower DR, Yewdall SJ, Polikarpov I, North AC, Sawyer L. Bovine $\beta$-lactoglobulin at $1.8 \AA$ resolution—still an enigmatic lipocalin. Structure. 1997;5(4):481-95.

2. Papiz MZ, Sawyer L, Eliopoulos EE, North AC, Findlay JB, Sivaprasadarao R, Jones TA, Newcomer ME, Kraulis PJ. The structure of beta-lactoglobulin and its similarity to plasma retinolbinding protein. Nature. 1986;324(6095):383-5.

3. Kontopidis G, Holt C, Sawyer L. Invited review: $\beta$-lactoglobulin: binding properties, structure, and function. J Dairy Sci. 2004;87:785-96.

4. Sawyer L, Kontopidis G. Review: the core lipocalin, bovine $\beta$ lactoglobulin. Biochim Biophys Acta. 2000;1482:136-48.

5. Mellor JD, Bell GA. Freeze-drying. In: Caballero B, Trugo LC, Finglas PM, editors. Encyclopedia of food sciences and nutrition. Oxford: Academic Press Elsevier Science Ltd.; 2003.

6. Mermelstein N. Spray drying. Food Technol. 2001;55(4):92-5.

7. Reineccius GA. Flavor encapsulation. Food Rev Int. 1989;5(1): 146-76.

8. Shrestha A, Howes T, Adhikari B, Wood B, Bhandari B. Effect of protein concentration on the surface composition, water sorption and glass transition temperature of spray-dried skim milk powders. Food Chem. 2007;104:1436-44.

9. Bhandari BR, Howes T. Implication of glass transition for the drying and stability of dried foods. J Food Eng. 1999;40:71-9.

10. Roos YH. Thermal analysis, state transitions and food quality. J Therm Anal Calorim. 2003;71:197-203.

11. Haque M, Roos Y. Water sorption and plasticization behaviour of spray-dried lactose/protein mixtures. J Food Sci. 2004;69(8):384-91.

12. Kasapis S. Definition and applications of the network glass transition temperature. Food Hydrocoll. 2006;20:218-28.

13. Wirkowska-Wojdyła M, Ostrowska-Ligęza E, Górska A, Koczoń P. Thermal properties of fats extracted from powdered baby formulas. J Therm Anal Calorim. 2012;110(1):137-43.

14. Ostrowska-Ligęza E, Górska A, Wirkowska-Wojdyła M, Koczoń P. An assessment of various powdered baby formulas by conventional methods (DSC) or FT-IR spectroscopy. J Therm Anal Calorim. 2012;110(1):465-71. 
15. Bryś J, Wirkowska-Wojdyła M, Górska A, Ostrowska-Ligęza E, Bryś A, Koczoń P. The use of DSC and FT-IR spectroscopy for evaluation of oxidative stability of interesterified fats. J Therm Anal Calorim. 2013;112(1):481-7.

16. Ostrowska-Ligęza E, Jakubczyk E, Górska A, Wirkowska-Wojdyła M, Bryś J. The use of moisture sorption isotherms and glass transition temperature to assess the stability of powdered baby formulas. J Therm Anal Calorim. 2014;118(2):911-8.

17. Bryś J, Wirkowska-Wojdyła M, Górska A, Ostrowska-Ligęza E, Bryśs A. Application of the calorimetric and spectroscopic methods in analytical evaluation of the human milk fat substitutes. J Therm Anal Calorim. 2014;118(2):841-8.

18. Reading M, Elliott D, Hill VL. MDSC, a new approach to the calorimetric investigation of physical and chemical transitions. J Therm Anal Calorim. 1993;40:949-55.

19. Reading M. Modulated differential scanning calorimetry-a new way forward in materials characterisation. Trends Polym Sci. 1983;1:248-53.

20. Pugliese A, Paciulli M, Chiavaro E, Muchetti G. Characterisation of commercial dried milk and some of its derivatives by differential scanning calorimetry. J Therm Anal Calorim. 2016;123(3):2583-90.

21. de Santana RF, de Oliveira Neto ER, Santos AV, Soares CMF, Lima AS, Cardoso JC. Water sorption isotherms and glass transition temperature of freeze-dried Sysygium cumini fruit (jambolan). J Therm Anal Calorim. 2015;120(1):519-24.

22. Haque MA, Chen J, Aldred P, Adhikari B. Drying and denaturation characteristics of whey protein isolate in the presence of lactose and trehalose. Food Chem. 2015;177:8-16.

23. Murray BS, Liang HJ. Evidence for conformational stabilization of $\beta$-lactoglobulin when dried with trehalose. Langmuir. 2000;16:6061-3.

24. Patist A, Zoerb H. Preservation mechanisms of trehalose in food and biosystems. Colloids Surf B. 2005;40:107-13.

25. Haque MK, Roos YH. Differences in the physical state and thermal behavior of spray-dried and freeze-dried lactose and lactose/protein mixtures. Innov Food Sci Emerg Technol. 2006;7:62-73.

26. Hogan SA, O'Callaghan DJ. Moisture sorption and stickiness behavior of hydrolysed whey protein/lactose powders. Dairy Sci Technol. 2013;93:505-21.

27. Islam MIU, Edrisi M, Langrish T. Improving process yield by adding WPI to lactose during crystallization and spray drying under high-humidity conditions. Dry Technol. 2013;31(4):393-404.

28. Górska A, Szulc K, Ostrowska-Ligęza E, Wirkowska M, Bryś J. The influence of trehalose-maltodextrin and lactose-maltodextrin matrices on thermal and sorption properties of spray-dried $\beta$-lactoglobulinvitamin $\mathrm{D}_{3}$ complexes. J Therm Anal Calorim. 2013;112:429-36.

29. Szulc K, Lenart A. Water vapour adsorption properties of agglomerated baby food powders. J Food Eng. 2012;109:135-41.

30. Kelly G, O’Mahony J, Kelly A, Huppertz A, Kennedy D, O'Callaghan D. Influence of protein concentration on surface composition and physico-chemical properties of spray-dried milk protein concentrate powders. Int Dairy J. 2015;51:34-40.
31. Jakubczyk E, Ostrowska-Ligęza E, Gondek E. Moisture sorption characteristics and glass transition temperature of apple puree powder. Int J Food Sci Technol. 2010;45:2515-23.

32. Rahman M, Al-Marhubi I, Al-Mahrouqi A. Measurement of glass transition temperature by mechanical (DMTA), thermal (DSC and MDSC), water diffusion and density methods: a comparison study. Chem Phys Lett. 2007;440:372-7.

33. Górska A, Ostrowska-Ligęza E, Szulc K, Wirkowska M. A differential scanning calorimetric study of $\beta$-lactoglobulin and vitamin $\mathrm{D}_{3}$ complexes. J Therm Anal Calorim. 2012;110(1):473-7.

34. Buera P, Schebor C, Elizalde E. Effects of carbohydrate crystallization on stability of dehydrated foods and ingredient formulations. J Food Eng. 2005;67:157-65.

35. Harnkarnsujarit N, Charoenrein S. Effect of water activity on sugar crystallization and ß-carotene stability of freeze-dried mango powder. J Food Eng. 2011;105:592-8.

36. Sitaula R, Bhowmick S. Moisture sorption characteristics and thermophysical properties of trehalose-PBS mixtures. Cryobiology. 2006;52:369-85.

37. James B. Advances in "wet" electron microscopy techniques and their application to the study of food structure. Trends Food Sci Technol. 2009;20:114-24.

38. Correia P, Leito A, Beiro-da-Costa ML. The effect of drying temperatures on morphological and chemical properties of dried chestnuts flours. Food Eng. 2009;90:325-32.

39. Wilson J. Microscopical methods for examining frozen foods. In: Bald WB, editor. Food freezing: today and tomorrow. London: Springer; 1991. p. 97-112.

40. Aguilera JM, Stanley DW, Baker KW. New dimensions in microstructure of food products. Trends Food Sci Technol. 2000;11:3-9.

41. Falcone PM, Baiano AC, Mancini L, Tromba G, Zanini F, Del Nobile M. Imaging techniques for the study of food microstructure: a review. In: Taylor SL, editor. Advances in food and nutrition research, vol. 51. New York: Elsevier; 2006. p. 205-63.

42. Krishnan S, Bhosale R, Singhal RS. Microencapsulation of cardamom oleoresin: evaluation of blends of gum Arabic, maltodextrin and a modified starch as wall materials. Carbohydr Polym. 2005;61:95-102.

43. Krokida M, Karathanos V, Maroulis Z. Effect of freeze-drying conditions on shrinkage and porosity of dehydrated agricultural products. Food Eng. 1998;35:369-80.

44. Anwar S, Kunz B. The influence of drying methods on the stabilization of fish oil microcapsules: comparison of spray granulation, spray drying, and freeze drying. Food Eng. 2011;105:367-78.

45. Oikonomopoulou V, Krokida M, Karathanos V. Structural properties of freeze-dried rice. Food Eng. 2011;107:326-33.

46. Rhim JW, Koh S, Kim JM. Effect of freezing temperature on rehydration and water vapor adsorption characteristics of freezedried rice porridge. Food Eng. 2011;104:484-91. 